http://doi.org/10.35784/iapgos.2579

\title{
GENERATING FIRE-PROOF CURTAINS BY EXPLOSION-PRODUCTION OF WATER AEROSOL AS AN ELEMENT OF FIRE-SAFETY ENGINEERING
}

\author{
Grzegorz Śmigielski
}

Kazimierz Wielki University, Institute of Computer Science, Bydgoszcz, Poland

Abstract. Parameters of a fire-quenching system based on explosive water-aerosol production and spreading are presented. Such a system with correctly tailored amounts of the water and the explosive material produces water-aerosol with high fire-quenching efficiency due to the small radii of the droplets and at the same time secures that shock-wave pressures are safe for the human body at distances exceeding $30 \mathrm{~m}$ from the explosion axis.

Keywords: explosive aerosol production, firefighting

\section{WYTWARZANIE ZAPÓR OGNIOWYCH REALIZOWANYCH POPRZEZ WYBUCHOWE WYTWARZANIE AEROZOLU WODNEGO JAKO ELEMENT INŻYNIERII BEZPIECZEŃSTWA POŻAROWEGO}

Streszczenie. Przedstawiono parametry instalacji gaśniczej opartej na wytwarzaniu i rozprzestrzenianiu się wybuchowego aerozolu wodnego. Taki system $z$ odpowiednio dobranymi ilościami wody i materiału wybuchowego wytwarza aerozol wodny o dużej skuteczności gaszenia pożaru dzięki małym promieniom kropelek i jednocześnie zapewnia, że ciśnienie fali uderzeniowej jest bezpieczne dla ludzi w odległości powyżej 30 m od osi wybuchu.

Słowa kluczowe: wybuchowe wytwarzanie aerozolu, gaszenie pożarów

\section{Introduction}

Production of water-aerosol with explosives is a new technology. Though the idea of using water-aerosol in firefighting and some its practical applications are widely known [9, $19,22]$. The novelty consists in the way of using the aerosol and in the scale of its production. Explosion-produced water-aerosol may be used for extinguishing large-scale fires provided it is produced in sufficiently large amount. Research on practical implementation of the idea of producing aerosol with explosive is being carried on for several years [4-7, 15-18]. The results obtained till now are very promising since high efficiency of this solution was achieved - fire of inflamed wooden boards, covering a disc of $30 \mathrm{~m}$ in diameter had been quenched with about $1000 \mathrm{dm}^{3}$ of water.

The method of producing aerosol by explosion may be used not only for fire extinguishing. There are many other potential applications and proliferation of the method and its implementation into industrial production will entail appearance of other applications. Such aerosol can be used for neutralization of chemically and/or radioactively contaminated areas, spraying vegetation with chemicals or deposition of munitions. Usage of the method for such diverse application requires only proper selection of the size of the bag and the kind of the liquid of which the aerosol is to be produced.

The explosive production of water-aerosol is in a number of ways related to the safety engineering. First, high firequenching efficiency of the method recommends it for using in generating fire-proof curtains. Second, the method generates some safety problems, and consequently, it is necessary to determine safety conditions for its applications. In particular it is necessary to determine the area around the explosion point in which shock wave pressure may be dangerous for people. Separate safety problems are connected with the process of production and storage of the water bags and fixing explosive charges inside them.

\section{Production of water-aerosol}

This publication is based on the idea of producing wateraerosol by explosive method. It consists in detonating explosive charge placed inside a water container. The detonation causes fragmentation (pulverization) of water into droplets that move symmetrically away from the explosion axis. The aerosol generated this way covers certain area which in particular may be in fire.

Water capsule, i.e., the container with water and explosive material (Fig. 1 for its schematic cross-section and Fig. 2 for its actual view) secures fixed position of the latter with respect to the artykuł recenzowany/revised paper contained bulk of water. The water - explosive system is expected to optimize production of water-aerosol cloud with droplets of small enough diameters and covering densely enough a desired area. In addition, the capsule's construction must fulfill safety requirements [21].

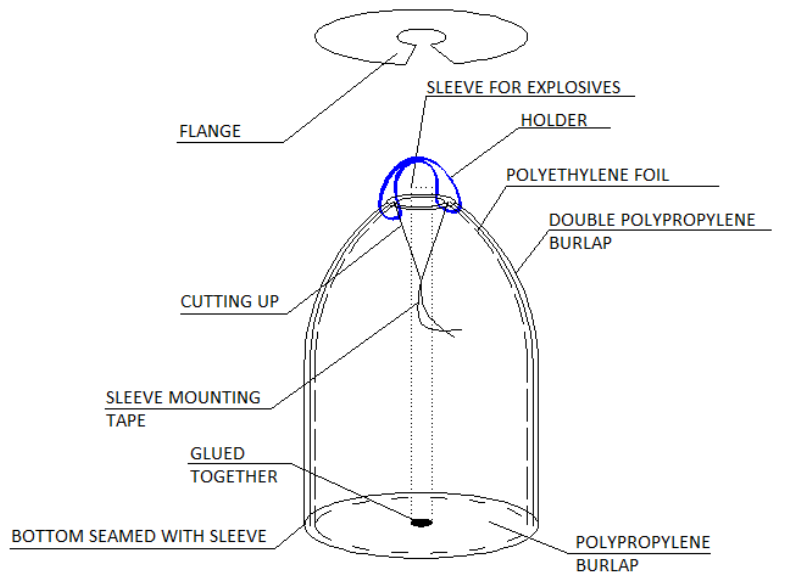

Fig. 1. Water capsule worked-out during field tests - scheme of the design

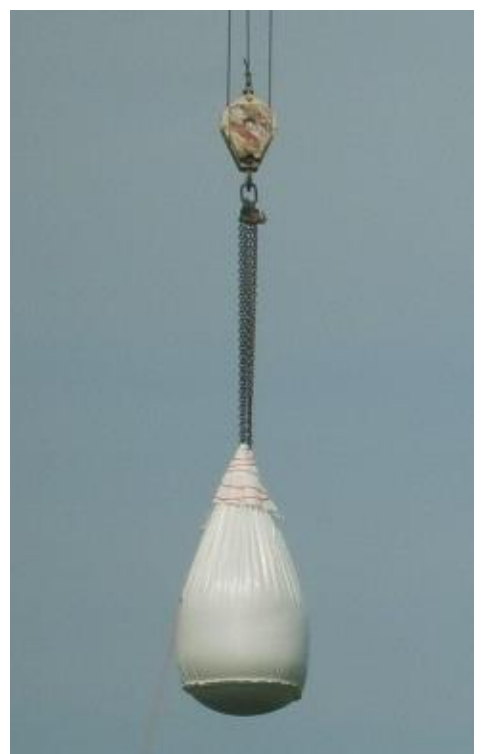

Fig. 2. Water capsule worked-out during field tests - the outer view of an actual capsule 
Submerging explosive in the water meets the above two requirements to a large degree, since it secures high efficiency of the explosion energy transfer to the bulk of water and quenching of the shock-way to the level safe for the humans even at moderate distances from the explosion axis [13]. The production cost, weight and suitability for storage and transportation are other factors that have to be taken into account while the commercial construction is considered.

\section{Parameters of water aerosol as fire- extinguishing agent}

The explosion ensues fragmentation of water contained in the capsule and acquiring certain initial axifugal velocity by the produced aerosol droplets. After several milliseconds from the explosion the droplets cease to accelerate and start to move with deceleration caused by the drag and friction caused by the air [7]. The drag force during the motion with large velocity is considerable and causes further fragmentation (called "stripping") of droplets [7, 12, 14]. This process continues till the size of droplets and their velocities are reduced to such values that the drag force is to small to cause further fragmentation. Therefore the sizes of aerosol droplets change in the course of cloud's expansion, and from the point of view of applications of explosive aerosoling it is the final droplet size that counts.

Explosive production of aerosol required some investigation of the prospects of practical application of the method. Among others it was necessary to measure: pressure of the shock-wave generated by the explosion, cloud's diameter and size of droplets. The research stand was shown in Fig. 3. and Fig. 4.

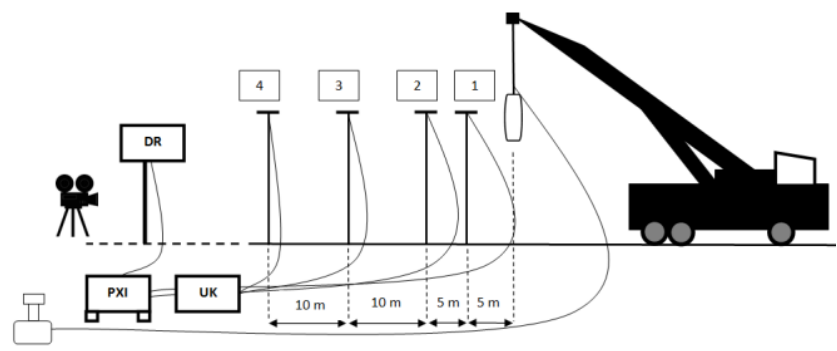

Fig. 3. Scheme of the research stand

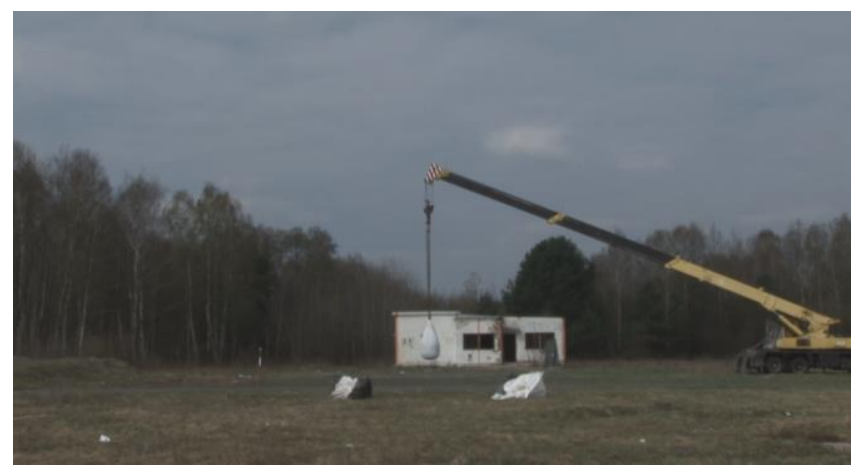

Fig. 4. The research stand before capsule's explosion

\subsection{Measurement of shock-wave pressure}

The apparatus was composed of a short-circuit detector, triggering measurement, four piezoelectric high pressure sensors (IEPE) $137 \mathrm{xx}$ series [26], a system of conditioning the signal (UK) [24] and an industrial NI PXI computer [23]. The points of the sensors are directed towards the explosion axis to reduce the drag force and to prevent blowing them out from the poles or from damage by expanding shock-wave and explosion products. To ensure comparable relative accuracy of pressure measurements at all four distances from the explosion axis, three types of sensors are used and their parameters are given in Table 1. A schematic view of the configuration of the sensors (no. 1 - no. 4) with respect to the water capsule is shown in Fig. 3.
The measurement is triggered on at the moment of explosion of the charge by the upset sensor inserted into the earlier. The measuring systems allows to register $10^{5}$ samples of pressure at the sampling frequency $5 \cdot 10^{5}$ samples per second. It allows one to cover time interval of $200 \mathrm{~ms}$ with time resolution $2 \mu \mathrm{s}$. Acquisition and processing of the results of measurements is made possible by an industrial PXI computer supplied with the software LabVIEW RT, and equipped with a measurement card. Timeprofiles of the shock-wave pressure registered by the measuring system allowed one to determine pressure distribution with respect to the distance from the explosion axis.

Table 1. Parameters of the pressure sensors

\begin{tabular}{|c|c|c|c|c|}
\hline $\begin{array}{c}\text { Number } \\
\text { of sensor }\end{array}$ & $\begin{array}{c}\text { Sensitivity } \\
K_{1} \\
{[\mathrm{mV} / \mathrm{kPa}]}\end{array}$ & $\begin{array}{c}\text { Maximum } \\
\text { pressure } \\
{[\mathrm{MPa}]}\end{array}$ & $\begin{array}{c}\text { Resolution } \\
{[\mathrm{kPa}]}\end{array}$ & $\begin{array}{c}\text { Expanded } \\
\text { uncertainty } \\
U_{r}\left(K_{1}\right)[\%] \\
(95 \%)\end{array}$ \\
\hline 1 & 0.149 & 34.5 & 0.69 & 1.3 \\
\hline 2 & 2.8 & 34.5 & 0.001 & 0.8 \\
\hline 3 & 15.1 & 6.9 & 0.069 & 0.8 \\
\hline 4 & 13.7 & 6.9 & 0.069 & 1.3 \\
\hline
\end{tabular}

The maximum pressures registered by the sensors for various conditions are shown in Fig. 5 - Fig. 8. The tests were conducted for three various capsule capacities $\left(600,1200\right.$ and $1500 \mathrm{dm}^{3}-$ size of the bubbles), three various types of explosives (EMULINIT [25] - red bubbles, Plastic C4 - yellow, Saletrol blue) and a number of explosion energies.

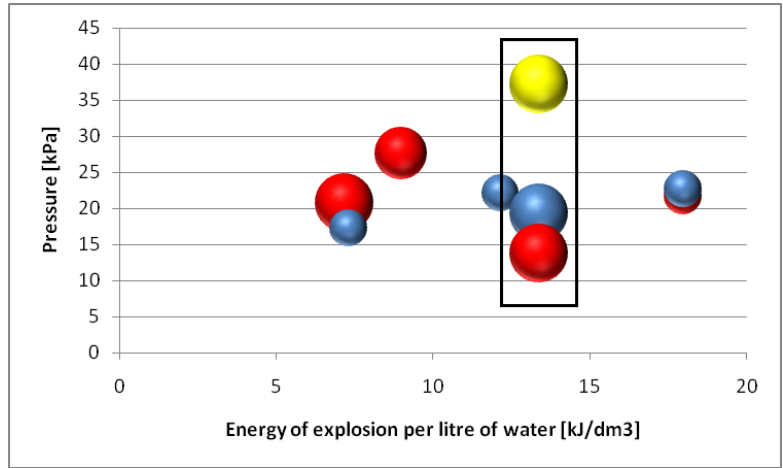

Fig. 5. Maximum pressure registered by sensor no. 1

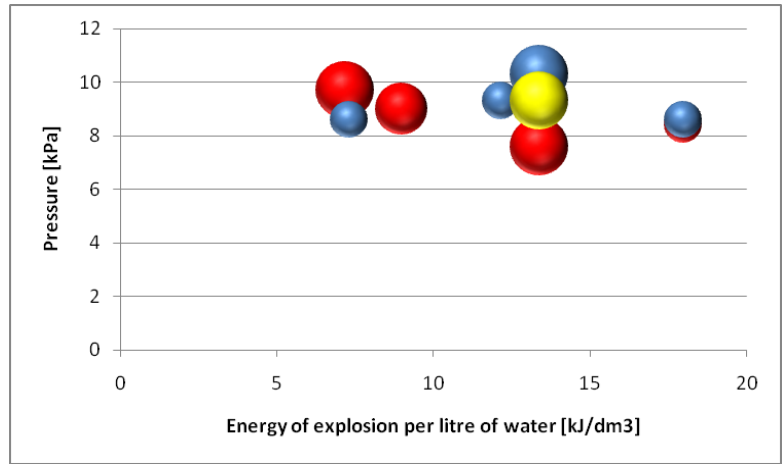

Fig. 6. Maximum pressure registered by sensor no. 2

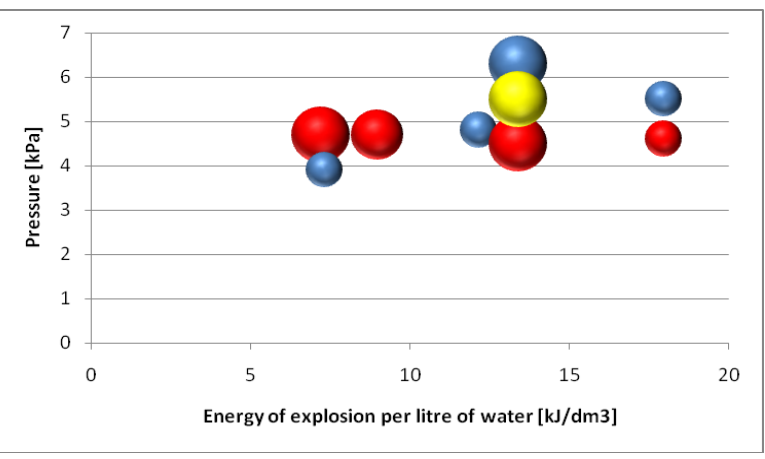

Fig. 7. Maximum pressure registered by sensor no. 3 


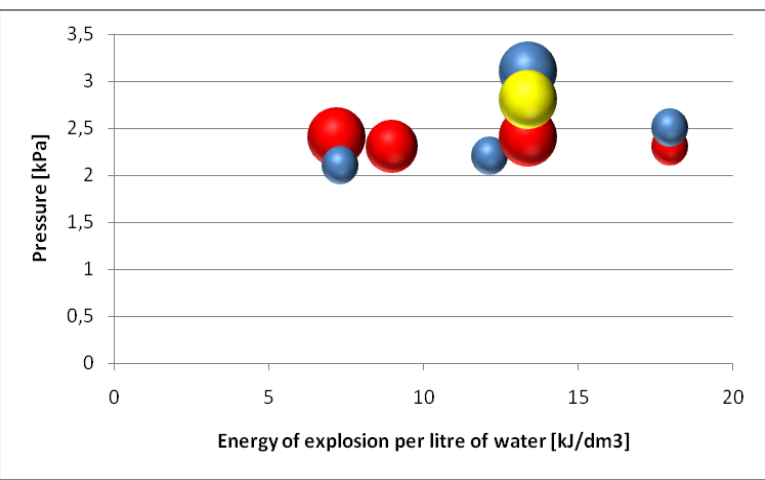

Fig. 8. Maximum pressure registered by sensor no. 4

Assuming that the pressure amplitude of the shock-wave front at a distance from the explosion axis is a measure of the "idle" energy, i.e. the energy that was not converted into the useful work over the water-bulk, the largest maximum pressure on the sensor No. 1 would correspond to the least efficient configuration and the smallest maximum to the most efficient configuration.

Looking specifically at the rectangle mark in Fig. 5 one can notice that for the same amount of water $-1500 \mathrm{~kg}$, and the same explosion energy - 20.1 MJ, which corresponds to $13.4 \mathrm{~kJ} / \mathrm{dm}^{3}$, various kinds of tested explosive materials exhibit various efficiencies. Apparently from this point of view Plastic (C4) seems to be the least efficient while EMULINIT seems to be the most efficient of the three explosive material tested.

The pressure in the shock-wave front $30 \mathrm{~m}$ from the explosion axis in no test (independent of the capsule capacity and explosion energy) exceeded $3 \mathrm{kPa}$ [7], i.e. about $3 \%$ of the normal atmospheric pressure, which is safe for the human body $[11,21]$.

The pressure measurements uncertainty is connected with errors of sensors and errors of measurement chain - signal conditioning system and input analog card.

The value of the pressure can be determined using the following relation [17]:

$$
p=\frac{U_{2}}{K_{1} K_{2}},
$$

where $K_{1}$ is a coefficient of the pressure/voltage processing, $U_{2}$ is measured voltage and $K_{2}$ is amplification of the signal conditioning system. The value of the sensors pressure measurements uncertainty has been determined based on the value of expanded uncertainty taken from calibration certificate (Table 1).

The overall uncertainty of the complex measurement has been evaluated based on the following expression $[1,17,20]$ :

$$
u(p)=\sqrt{\left(\frac{\partial p}{\partial K_{1}}\right)^{2} u^{2}\left(K_{1}\right)+\left(\frac{\partial p}{\partial K_{2}}\right)^{2} u^{2}\left(K_{2}\right)+\left(\frac{\partial p}{\partial U_{2}}\right)^{2} u^{2}\left(U_{2}\right)},
$$

The maximum uncertainty values for individual sensors were: $u_{1}(p)=0.22 \mathrm{kPa}, u_{2}(p)=0.067 \mathrm{kPa}, u_{3}(p)=0.026 \mathrm{kPa}$, $u_{4}(p)=0.021 \mathrm{kPa}$.

\subsection{Measurement of cloud's diameter}

Measurements of cloud's diameter had to be performed indirectly. The method used during our experiments was based on registration of the process of expansion with a fast video camera working at the frequency $250 \mathrm{fps}$. The camera was placed at a distance from the axis of explosion much larger than the maximum cloud's diameter (Fig. 3, Fig. 4, Fig. 9). This way it was safe against possible influence by the shockwave and, in addition, its distant position of the helped to minimize parallax error.

The diameter of the cloud was estimated from subsequent frames by its comparison with the reference scale indicated either by stakes (Fig. 4). The results of measurements are presented in Table 2 .
Analyzing a number of tests it has been found that the maximal error of the cloud diameter measurement can be associated with a cloud spreading time, for the time over $2 \mathrm{sec}$ it is on $\Delta x=2 \mathrm{~m}$ [17].

In general, for bags of the same size increase of cloud's diameter is observed with increase explosion energy up to a limiting energy value that depends on the water-bag size. Using energies exceeding the limiting value results in quite a pronounced decrease of cloud's diameter, which can be interpreted in terms of the breakdown of efficiency of energy transfer to the waterbulk. In the case of energies below the limiting values the shockwave can be perceived at distances larger than $50 \mathrm{~m}$ only acoustically. On the contrary, while the limiting energy value is exceeded, the shock-wave can be perceived directly by observers as a "blow", and can cause some damages to objects like cars even that far as $100 \mathrm{~m}$ from the explosion axis.

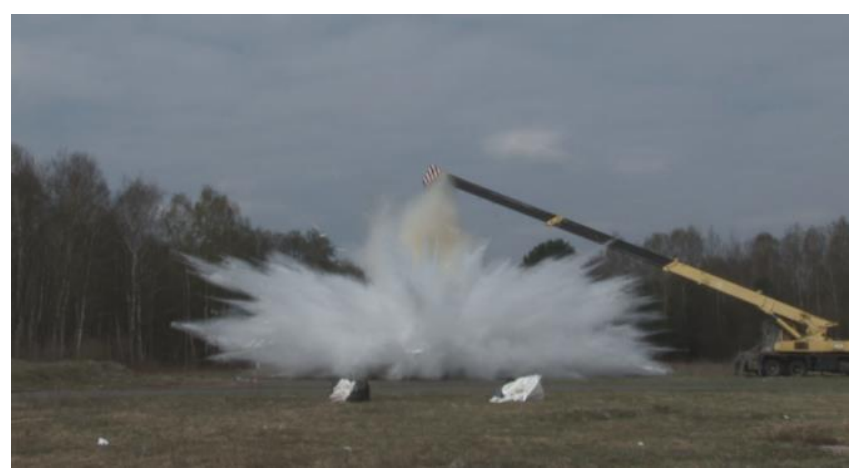

Fig. 9. The aerosol cloud a few dozen milliseconds after the explosion

Table 2. The maximum spray cloud diameter (Emulinit)

\begin{tabular}{|c|c|c|}
\hline $\begin{array}{c}\text { Capsule } \\
\text { capacity }\end{array}$ & $\begin{array}{c}\text { Explosion } \\
\text { energy }\end{array}$ & $\begin{array}{c}\text { Cloud } \\
\text { diameter }\end{array}$ \\
\hline $\mathrm{dm}^{3}$ & $\mathrm{~kJ}$ & $\mathrm{~m}$ \\
\hline 600 & 4384 & 24 \\
\hline 600 & 7293 & 32 \\
\hline 1200 & 7293 & 38 \\
\hline 1200 & 13110 & 38 \\
\hline 1200 & 16601 & 41 \\
\hline 1500 & 10784 & 40 \\
\hline 1500 & 13110 & 47 \\
\hline 1500 & 16601 & 49 \\
\hline 1500 & 20092 & 53 \\
\hline
\end{tabular}

\subsection{Measurement of droplets size}

In this section results of measurements of explosion-produced aerosol droplets are presented. The method of measurement, called optical method [4, 18] applied droplet recorder - an apparatus located in the line of droplets' trajectories (Fig. 3 -DR).

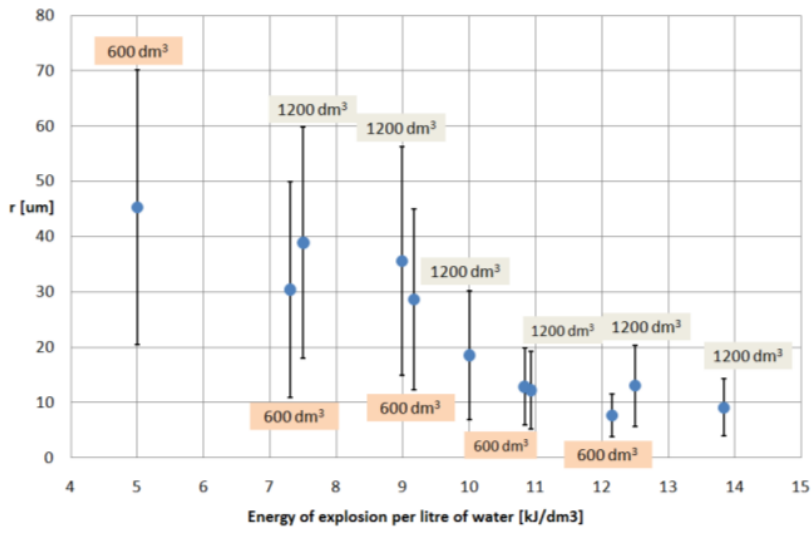

Fig. 10. Dependence on the explosion energy of the average droplet radius (approximating expectation value of their distribution) together with measurement uncertainty equal to the standard deviation 
Determination of the radius distribution of droplets in this method was based on collecting them on a glass plate and measuring diameters of adhering droplets using microscope. The shutter is the core of the recorder. It opens with time delay (with respect to explosion) and for time interval chosen by the operator under the control of the recorder driver [4, 18].

The optical method allows one to measure sizes of aerosol droplets inside the cloud. In Fig. 10. a plot of average droplet radius versus the explosion energy per 1 litre of sprayed liquid is shown. The average radii range from about $7 \mu \mathrm{m}$ to about $45 \mu \mathrm{m}$.

\section{Summary}

Water aerosol is a perfect fire-extinguishing agent whose fire quenching efficiency surpasses many times that of jets of water. In the case of explosive aerosoling the fire-extinguishing effect is enhanced by the shock-wave. The fire-extinguishing properties can be further enhanced and modified by adding various admixtures to the basic medium, which can considerably extend the range of its application.

The research performed for three different types of the explosive charge: Saletrol (ANFO), Emulinit and plastic explosive (C4) showed that the Emulinit is most efficient in creation of the aerosol cloud.

Basic parameters of the water-capsule, which have been established are shown in Table 3. The amount of the explosive material used for the production of aerosol is chosen depending on the size of the capsule to secure reduction of the shock-wave pressure amplitude to the level secure for human body at distances from the axis of explosion larger than $30 \mathrm{~m}[13,21]$.

Table 3.Basic parameters of water-capsule

\begin{tabular}{|c|c|c|c|c|c|c|}
\hline \multirow{2}{*}{$\begin{array}{l}\text { Capacity } \\
\text { of } \\
\text { water- } \\
\text { capsule }\end{array}$} & \multirow{2}{*}{$\begin{array}{l}\text { Bottom } \\
\text { diameter }\end{array}$} & \multirow{2}{*}{$\begin{array}{c}\text { Container } \\
\text { height }\end{array}$} & \multicolumn{3}{|c|}{$\begin{array}{l}\text { Amount of the main explosive } \\
\text { charge (Emulinit 2) }\end{array}$} & \multirow{2}{*}{ 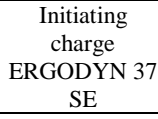 } \\
\hline & & & Ver. A & Ver. B & Ver. C & \\
\hline $\mathrm{dm}^{3}$ & $\mathrm{~mm}$ & $\mathrm{~mm}$ & \multicolumn{3}{|c|}{ dag } & $\mathrm{g}$ \\
\hline 600 & 900 & 1250 & 125 & 250 & 400 & 500 \\
\hline 1200 & 900 & 1650 & 400 & 500 & 650 & 500 \\
\hline 1800 & 900 & 2200 & 500 & 650 & 800 & 500 \\
\hline
\end{tabular}

Generation of fire-proof aerosol curtains remains in the area of interest of the safety engineering. Applying water-capsules for production of such curtains seems to be a reasonable idea. All experiments and measurements performed by us provided evidences in favor of large potential of such a solution. Further research will certainly help to exploit this potential to a larger degree. A common danger caused by fires should be a sufficient justification for further research. Novelty of our research consists not that much in the idea of explosive generation of aerosol as in the scale of such production. Production of water-aerosol on the scale discussed in this publication was not reported by any other research group, although aerosoling of amounts of liquid smaller by three orders of magnitude was investigated $[2,3,10,12]$. That, however, was not sufficient from the point of view of practical applications.

\section{Acknowledgments}

The author is grateful to Prof. Roman Dygdała and Dr. Eng. Damian Lewandowski for his assistance and collaboration during the tests on military training area and analysis of the results.

\section{References}

[1] Arendarski J.: Niepewność pomiarów. OWPW, Warszawa 2006.

[2] Brenguier J., Pawlowska H., Schüller L., Preusker R., Fischer J., Fouquart Y : Radiative Properties of Boundary Layer Clouds: Droplet Effective Radius Versus Number Concentration. J. Atm. Sci. 57/2000, 803-821.

[3] Breon F., Goloub P.: Cloud Droplet Effective Radius From Space Borne Polarization Measurements. Geophys. Res. Lett. 25/1998, 1879-1882.

[4] Chaberski D., Grzelak S., Lewandowski D., Dygdała R., Zieliński M., Stefański K., Śmigielski G.: Measuring Distribution of Radii of Droplets Forming Explosively Generated Water-Spray Cloud. Metrol. Meas. Syst. 3/2010, 363-382.

[5] Dygdała R., Stefański K., Śmigielski G., Lewandowski D., Kaczorowski M. Aerosol Produced by Explosive Detonation. Pomiary, Automatyka, Kontrola 53(9)/2007, 357-360.

[6] Kuhrt E., Knollenberg J., Martens V.: An automatic early warning system for forest fires. Annals of Burns and Fire Disasters 14/2001, 151.

[7] Lewandowski D.: Wytwarzanie aerozolu wodnego metodą wybuchową aspekty metrologiczne, Praca doktorska. Politechnika Wrocławska. Wrocław 2011 .

[8] Lewicki J.: Prognozowanie wielkości zagrożeń powstałych przy prowadzeniu robót strzałowych w budownictwie. Górnictwo i Geoinżynieria 28(3/1)/2004, 251-267.

[9] Liu Z., Kim A. K., Carpenter D.: Extinguishment of large cooking oil pool fires by the use of water mist systems. Combustion Institute/Canada Section, Spring Technical Meeting, 2004, 1-6.

[10] Morka A. Wybuchowe rozpraszanie cieczy, PWN, Warszawa 2001.

[11] Onderka Z., Sieradzki J., Winzer J.: Wpływ robót strzelniczych na otoczenie kopalń odkrywkowych. UWND AGH, Kraków 2003.

[12] Papliński A.: Modelowanie spalania i wybuchu w niejednorodnych fizycznie ośrodkach reaktywnych. Wojskowa Akademia Techniczna, Warszawa 2009.

[13] Rosenkiewicz D., Bogdański M., Zarzycki J., Łabędzki J.: Analiza parametrów fal podmuchowych generowanych ładunkami gaśniczymi. II Międzynarodowa Konferencja IPOEX 2005: Materiały wybuchowe, Badania - Zastosowanie Bezpieczeństwo, Tom I, 2006

[14] Stebnovskii S. V.: Pulsed Dispersion as the Critical Regime of Destruction of a Liquid. Combustion, Explosion, and Shock Waves 44(2)/2008, 228-238.

[15] Stefański K., Lewandowski D., Dygdała R., Kaczorowski M., Ingwer-Żabowska M., Śmigielski G., Papliński A.: Explosive formation and spreading of waterspray cloud - experimental development and model analyses. Central European Journal of Energetic Materials 6(3-4)/2009, 291-302.

[16] Śmigielski G., Toczek W., Dygdała R., Stefański K.: Metrological Analysis of Precision of The System of Delivering Water-Capsule for Explosive Production of Water Aerosol. Metrol. Meas. Syst. XXIII(1)/2016, 47-58.

[17] Śmigielski G., Dygdała R., Kaczorowski M., Serejko G.: Measurements of Parameters of Water Aerosol Obtained by Explosive Method. Informatyka, Automatyka, Pomiary w Gospodarce i Ochronie Środowiska IAPGOŚ 3/2016, 32-35.

[18] Śmigielski G. et. al.: Rejestrator kropel aerozolu wodnego wytwarzanego metodą wybuchową. PAK 60(12)/2014, 1170-1173.

[19] Teie W.: Firefighter's Handbook of Wildland Firefighting. Dear Valley Press, Recue 1994.

[20] Zięba A.: Analiza danych w naukach ścisłych i technice. PWN, Warszawa 2013.

[21] Dz. U. Nr 163, poz. 1577 - Rozporządzenie ministra gospodarki, pracy i polityki społecznej w sprawie bezpieczeństwa i higieny pracy przy produkcji, transporcie wewnątrzzakładowym oraz obrocie materiałów wybuchowych, w tym wyrobów pirotechnicznych.

[22] http://www.telesto.pl

[23] http://www.ni.com

[24] http://www.vibx.pl

[25] http://www.nitroerg.pl

[26] http://www.pcb.com

\section{Ph.D. Grzegorz Śmigielski}

e-mail: gsmigielski@ukw.edu.pl

Graduate of Faculty of Physics, Astronomy and Applied Informatics Nicolaus Copernicus University in Torun. He received the Ph.D. degree in electronics from Gdańsk University of Technology, Faculty of Electronics, Telecommunications and Informatics in 2011. His main scientific interests are control and measurement systems.

http://orcid.org/0000-0003-3781-0894

otrzymano/received: 28.02 .2021

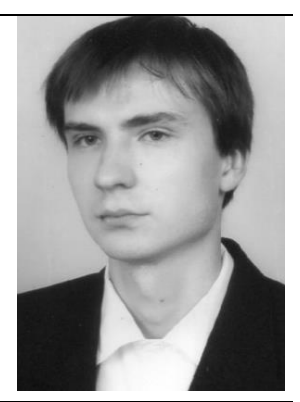

przyjetto do druku/accepted: 15.03 .2021 